\title{
FRESCO PAINTINGS OF SOUTHWEST CRIMEA CAVE CHURCHES ACCORDING TO IGOR GRABAR
}

\author{
Yuriy M. Mogarichev \\ Institute of Archaeology of Crimea of the Russian Academy of Sciences, Simferopol, Russian Federation; \\ Crimean Republican Institute of Postgraduate Pedagogical Education, Simferopol, Russian Federation
}

\begin{abstract}
Alena S. Ergina
Saint Petersburg State Academy of Arts and Design named after A.L. Stieglitz, Saint Petersburg, Russian Federation

Abstract. Introduction. Today, the remains of fresco paintings are preserved in six cave churches of Taurica: the temple of the Southern Monastery (Mangup); church in the field of Kielse-Tubu (district of Mangup); the temple of the Assumption and the Three Horsemen (Eski-Kermen); the Donators Temple (district of Eski-Kermen); the church number 12 on Zagaytansky rock (Inkerman). Authors of the $19^{\text {th }}$ - early $20^{\text {th }}$ centuries left descriptions of the now lost murals of six more monuments. Methods. Frescos of Crimean cave churches in historiography received insufficient comprehension. Only one monograph was published on this issue (1966). Analysis. Opinions and comments regarding the mural paintings of the cave churches of Crimea, expressed by reputable art historians and specialists in fresco paintings, are relevant. These include Igor Grabar. He was in Crimea in 1927, as the head of the Central Art Conservation Center by Glavnauka of the RSFSR. The Manuscript Department of the State Tretyakov Gallery stores leaflets from the notebook "Igor Grabar's trip notes in the Crimea and about Old Russian art". Authors publish the full text of Igor Grabar's notes concerning the murals of cave churches: the temple of the Assumption and the Three Horsemen (Eski-Kermen); the Donators Temple (district of Eski-Kermen); the temple of the Southern Monastery (Mangup). Results. Igor Grabar's notes help us clarify many points of view in the study of frescos of cave temples in Crimea. The study of the murals of the temple of the Three Horsemen by Igor Grabar allows us to justifiably discard the versions of "three Georges" and "portraits of real local figures". There are images of three holy warriors: Dmitry, Theodore (Stratilates or Tyrone), and George in the cave temple. The study of the Mangup Church fresco by Igor Grabar allowed us to develop a periodization of the formation of fresco paintings of this monument.
\end{abstract}

Key words: Byzantium, Crimea, Mangup, Eski-Kermen, "cave town”, frescos, I. Grabar.

Citation. Mogarichev Yu.M., Ergina A.S. Fresco Paintings of Southwest Crimea Cave Churches According to Igor Grabar. Vestnik Volgogradskogo gosudarstvennogo universiteta. Seriya 4. Istoriya. Regionovedenie. Mezhdunarodnye otnosheniya [Science Journal of Volgograd State University. History. Area Studies. International Relations], 2020, vol. 25, no. 6, pp. 116-130. (in Russian). DOI: https://doi.org/10.15688/jvolsu4.2020.6.8

\section{ФРЕСКОВЫЕ РОСПИСИ ПЕЩЕРНЫХ ЦЕРКВЕЙ ЮГО-ЗАПАДНОЙ ТАВРИКИ: ВЕРСИЯ И.Э. ГРАБАРЯ}

\section{Юрий Миронович Могаричев}

Институт археологии Крыма РАН, г. Симферополь, Российская Федерация; Крымский республиканский институг постдипломного педагогического образования,

г. Симферополь, Российская Федерация

\section{Алена Сергеевна Ергина}

Санкт-Петербургская государственная художественно-промышленная академия им. А.Л. Штиглица, г. Санкт-Петербург, Российская Федерация 
Аннотация. Введение. Сегодня остатки фресковых росписей сохранились в шести пещерных церквях Таврики: храме Южного монастыря (Мангуп), церкви на поляне Кильсе-Тубю (округа Мангупа), церквях «Успения» и «Трех всадников» (Эски-Кермен), храме «Донаторов» (округа Эски-Кермена), церкви № 12 на Загайтанской скале (Инкерман). Авторы XIX - начала XX в. оставили описания ныне утраченной стенописи еще шести памятников. Meтоды. Росписи пещерных церквей Крыма в историографии получили недостаточное освещение. По данной проблеме была опубликована лишь одна монография (1966 г.). Анализ. Актуальными представляются мнения и замечания, касающиеся стенописи пещерных церквей Крыма, высказанные авторитетными исследователямиискусствоведами, специалистами по фресковым росписям. К таковым относится И.Э. Грабарь. В Крыму он оказался в 1927 г. как руководитель экспедиции Центральных государственных реставрационных мастерских при Главнауки РСФСР. В Отделе рукописей Государственной Третьяковской галереи хранятся листки из записной книжки «Черновые заметки И.Э. Грабаря о поездке в Крым и о древнерусском искусстве». Авторы публикуют полный текст записей И.Э. Грабаря, касающихся стенописи пещерных церквей «Успения» и «Трех всадников», храма «Донаторов», храма Южного монастыря. Результатыл. Заметки И.Э. Грабаря помогают уточнить многие дискуссионные моменты в изучении фресковых росписей пещерных церквей Крыма. Касательно росписей храма «Трех всадников» заключение И.Э. Грабаря позволяет обоснованно отбросить версии о «трех Георгиях» и «портретах реальных местных деятелей». Перед нами изображение трех святых воинов: Дмитрия, Феодора (Стратилата или Тирона) и Георгия. Замечание академика о нескольких этапах формирования стенописи, сделанное в отношении мангупской церкви, позволило авторам разработать периодизацию формирования фресковых росписей данного памятника. Вклад авторов. Ю.М. Могаричевым подготовлены разделы об историографии и особенностях рассматриваемых памятников. А.С. Ергиной исследовались искусствоведческие аспекты.

Ключевые слова: Византия, Крым, Мангуп, Эски-Кермен, «пещерные города», фрески, И.Э. Грабарь.

Цитирование. Могаричев Ю. М., Ергина А. С. Фресковые росписи пещерных церквей Юго-Западной Таврики: версия И.Э. Грабаря // Вестник Волгоградского государственного университета. Серия 4, История. Регионоведение. Международные отношения. -2020. - Т. 25, № 6. - C. 116-130. - DOI: https://doi.org/10.15688/ jvolsu4.2020.6.8

Введение. В настоящее время остатки фресковых росписей сохранились в шести пещерных церквях Горной Юго-Западной Таврики: храме Южного монастыря (Мангуп) [12, c. 64-66; 14], церкви на поляне Кильсе-Тубю (округа Мангупа) [12, с. 69; 14], церквях «Успения» $[12$, с. 46-49; 15, с. 259-261] и «Трех всадников» [12, с. 49-51; 15, с. 261-263, 275276] (Эски-Кермен), храме «Донаторов» (округа Эски-Кермена) [12, с. 51-53; 15, с. 265268], церкви № 12 на Загайтанской скале (Инкерман) [2]. Авторы XIX - начала XX в. оставили описания ныне практически утраченной стенописи еще шести памятников: церкви Св. Георгия (Климента) [12, с. 9-11], «Храма с крещальней» [12, с. 11-13], церкви «География (Евграфия)» [12, с. 16-17], церкви монастыря Св. Георгия [12, с. 27] (все Инкерман), главного храма Шулдана [12, с. 36-37]; церкви «Судилище» (Эски-Кермен) [12, с. 44-46].

Методы. В связи с незначительным числом памятников и плохой сохранностью большинства из них, в историографии фресковые росписи пещерных церквей Крыма получили недостаточное освещение. По данной проблеме была опубликована лишь одна мо- нография - «Фрески средневекового Крыма» [9] О.И. Домбровского. При этом несколько разделов данной книги посвящены фрескам наземных храмов [9, с. 51-77], а внимание автора привлекли не все, даже сохранившиеся тогда, росписи (например, церковь на поляне Кильсе-Тубю). В этой связи важными представляются мнения и замечания, высказанные авторитетными исследователями-искусствоведами, специалистами по фресковым росписям. Таковым, несомненно, является академик И.Э. Грабарь.

Анализ. В Крым И.Э. Грабарь приехал в 1927 г. как руководитель экспедиции Центральных государственных реставрационных мастерских при Главнауки РСФСР. Данная поездка «ставила своей целью не только выявление и описание памятников, но и укрепление, частичную расчистку и небольшой ремонт» [6, с. 254]. Все это проходило в рамках подготовки на государственном уровне реестра памятников, подлежавших охране.

Экспедиция И.Э. Грабаря в Крым продлилась всего две недели (с 24 апреля по 5 мая 1927 г.). Особое внимание было уделено монументальным росписям «пещерных 
городов». В Отделе рукописей Государственной Третьяковской галереи (ОР ГТГ) хранится записная книжка «Черновые заметки И.Э. Грабаря о поездке в Крым и о древнерусском искусстве» [20]. Отдельные выписки оттуда были опубликованы в посмертной монографии И.Э. Грабаря «О древнерусском искусстве» в качестве примечаний раздела «Письма из Крымской экспедиции» [6, с. 254258]. Там также было помещено несколько страниц с зарисовками карандашом [6, с. 254259]. В «Черновых заметках» имеется описание стенописи пещерных церквей Мангупа и Эски-Кермена [10]. В целом рассматриваемую рукопись по ее содержанию можно разделить на две части: 1) черновые заметки, которые содержат краткие записи и быстрые линейные рисунки с пометками подписей святых и цветовыми характеристиками стенописи; 2) дневник о поездке в Крым. В последнем отмечены даты, время, место и яркие впечатления дня [20, л. 19-21].

Интересный отклик о данной экспедиции приводится у Н.Л. Эрнста: «Весной этого (1927 г. - Ю. М., А. Е.) пещерные церкви с росписями были посещены при нашем руководстве экспедицией Центральных реставрационных мастерских... под начальством И.Э. Грабаря... Нам было ценно и в вопросе о датировке росписей найти полное подтверждение нашего мнения, что они относятся к XIV или началу XV века и являют определенные черты палеологовской эпохи» [21, с. 34].

В настоящей работе, чтобы представить всеобъемлющую позицию И.Э. Грабаря по поводу стенописи пещерных церквей Таврики, мы публикуем полные выписки из его рукописи и наши пояснения о рассматриваемых памятниках.

\footnotetext{
Церковь Южного монастыря Мангупа (рис. 1,2) ${ }^{1}$.

«30 IV 1927 г. Ночевка в Мангубе 2 .

Мангуб. Церковь пещерная. Фрески начала $X I V$ в. [20, л. 20].

Церковь пещерная в Мангуп-Кале.

Слева от алтарной ниши три отца церкви. Ясно видим и справа три, видимо. Видны, по крайней мере, следы 3-х нимбов, надпись у Златоуста и крестчатые одежды у всех трех (лучше всех средний). Справа также кресчатость, фрагмент. Лучше всех левые ризы...
}

Спас, направо Иоанн Предтеча, налево Богоматерь, между ними и престолом по херувиму (левый сохранился сравнит., правого почти нет).

Следы на алтарном престоле и на откосах окна, что $<$...> было расписано. Все было видимо в XIV в. живопись, и в XV-XVI поновлено. Вверху у Спаса на Евангелие есть <...> черные буквы и белые поздние, над которыми старшие открываются.

Налево, на северной стене алтарной апсиды также два типа букв: по старым черными светлые буквы.

В алтарной нише сверху орнамент» [20, л. 8].

Храм расположен в южном обрыве мангупского плато и входит в комплекс Южного монастыря. Стенопись здесь можно разделить на композиции апсиды, роспись карниза алтарной арки и изображения святых на сводах церкви (рис. 3). Выделяются три этапа ее формирования. Вероятно, церковь впервые расписана в 20-30-х гг. XV века. Более поздние росписи могут датироваться периодом между 30-ми гг. XV в. и 1475 г., когда Мангуп был захвачен турками-османами. Фресковые росписи данного памятника была нами подробно рассмотрены ранее [13].

\section{Храм «Трех всадников».}

«В 6 ч-у выехали в Черкес-Кермен (Эски-Кермен). К $81 / 2$ ч. поднялись на вершину. Сняли 2 иеркви без фресок. Пришли в погребение с фреской Дм. Солунского (?), Георгия и Феодора Стратилата (?) [20, л. 20].

Фреска несомн[енно] ранняя, принадлежащая большому автору. Левый всадник на белом коне, средний на булатном, правый - на рыжем. Остатки вохрения первого прекрасны. Плащ его свободно развевается слева от него. Фрагменты одежды с пробелами мастерские. Очень ясно видна поза, тоже говорящая за реалистическую трактовку. Второй конь вскачь. Щиты у всех разные. Палеография раньше Мангубской. Плащ у левого холодно-зеленого (cветло-серого оттенка), у среднего малиново-багровый $(c<\ldots>)$, у правого оранжевый. У всех копья. Все повороты изысканные и не повторяющие друг друга. "Высечены и написаны святые мученики христовы да упокой души и прощение грехов". Все это на северо-восточной части. Санкирь светлозеленая: "румяна"» [20, л. 9].

Церковь расположена на юго-восточном склоне городища Эски-Кермен. Она вырублена в отдельном обломке скалы и свое название получила от фрески, расположенной на 
северной стене, на которой изображены три святых воина, сидящие на конях (рис. 4).

Роспись высотой 1,85 м и максимальной шириной 3,4 м (по фризу с надписью). Н.И. Репников подчеркивал: «Возникает вопрос, был ли храм расписан полностью или роспись ограничивалась описанным изображением. Утверждаем последнее на основании следующего соображения. Грунт изображения заготовлен враз, не имеет ни разрывов, ни швов, был по сырой штукатурке расписан сразу. На стенах нет ни малейшего намека на штукатурку, гладкая их поверхность, выровненная зубаткой, не удержала бы известкового намета. Позднейших переделок в храме нет, приведенный текст надписи говорит, что роспись одновременная устройству самого храма» [19, с. 108-109]. Н.Е. Гайдуков утверждает, что фреска не относится к настоящему храму: она появилась при его перестройке. Чтобы получилась гладкая поверхность по росписи, были подтесаны стена и потолок [5, с. 170-172]. Такой подход представляется ошибочным. Как отмечалось, Н.И. Репников доказал хронологическое тождество фресковой росписи и храма $[19$, c. 108-109]. В этой связи заметим, что, прежде чем наносить росписи на стену (особенно скальную), ее всегда дополнительно сглаживали. Так как стенопись занимает лишь часть стены, то, следовательно, специально подтесали именно тот участок, где должна помещаться фреска. И наконец, смысл надписи под фреской (см.: [15, с. 275-276]) однозначно свидетельствует (при всех нюансах перевода), что живописец связывал воедино вырубку и роспись храма.

Первое описание фрески церкви «Трех всадников» составил А.С. Уваров. По его мнению, здесь запечатлены слева направо: св. Дмитрий, св. Георгий, св. Федор Стратилат (как вариант в последнем случае св. Прокопий или св. Меркурий). Д.М. Струков писал, что на фреске помещены арх. Гавриил, свв. Георгий и Дмитрий (см.: [8, с. 61]). А.Л. Бертье-Делагард, по данным В.В. Латышева, считал, что это «св. Георгий в трех различных положениях во время борьбы с драконом» $[11$, с. 152]. По мнению Н.Л. Эрнста, там изображены: св. Георгий или Федор Стратилат, Дмитрий Солунский и Федор Тирон.
Но скорее всего, два свв. Федора и св. Георгий. Последнее заключение было сделано на основании того, что в «Камеральном описании Крыма» (1783) в деревне Черкес-Кермен упомянута церковь «двух Федоров», которую исследователь соотнес с «Тремя всадниками». Храм Н.Л. Эрнст датировал XIV-XV веками. И.Э. Грабарь так интерпретировал стенопись: «Дм. Солунский (?), Георгий и Феодор Стратилат (?)». Н.И. Репников, основываясь на мнении В.М. Григоровича, который в 1873 г. якобы разглядел на фреске дату 6712 гг., датировал создание храма XIII веком. Ученый отметил, что имен святых не сохранилось. А.Л. Якобсон полагал, что на росписях помещен только св. Георгий, а сами они принадлежат руке большого мастера XIII века. О.И. Домбровский рассматривал так изображенных: в центре Георгий Победоносец, а по бокам от него - местные воины, павшие в боях, над могилою которых и был сооружен мартирий. Версию о «трех Георгиях» исследователь считал необоснованной. С гипотезой О.И. Домбровского не согласилась Е.Г. Овчинникова, которая полагает, что на росписях изображен только св. Георгий, представленный в сюжетах: «чудо со спасенным из плена пафлагонским отроком»; «поражение копьем дракона»; «надежного защитника, готового прийти на помощь». А.В. Мальгин и М.Р. Мальгина вернулись к предположению Н.Л. Эрнста, дополнив его рядом аргументов. Ю.М. Могаричев считает, что росписи изображают Дмитрия Солунского, Федора Стратилата и Георгия Победоносца, как сначала и предполагал Н.Л. Эрнст. Церковь же «двух Федоров», скорее всего, находилась в соседней Черкес-Керменской балке. Э.М. Корхмазян посчитала, что церковь «Трех всадников» принадлежала армянской общине, а на фреске изображен св. Саркис с сыном Мартиросом. В.П. Степаненко и А.Ю. Виноградов также писали о тройственном изображении св. Георгия. И.Г. Волконская пришла к выводу, что храм «Трех всадников» имеет связь с другим пещерным храмом городища - «Успения». По ее мнению, обе церкви были расписаны одной артелью мастеров в один и тот же сезон. А произошло это в последней четверти XIII в. (подробнее историография рассмотрена в: [15, с. 274-278]) ${ }^{3}$. Однако после- 
днее умозаключение сделано на основании некорректной выборки штукатурки для анализа в указанных памятниках. В результате все доводы исследовательницы сводятся на нет [8, с. 56-59]. Болгарский исследователь Г. Атанасов, специально занимавшийся эволюцией изображений св. Георгия, считает, что на фреске изображены св. Дмитрий, св. Феодор и св. Георгий [1, с. 248-249]. Е.Н. Осауленко пришел к выводу, что всадник-змееборец - это св. Феодор [17, с. 131]. Немецкая исследовательница А. ПлонткеЛюнинг - сторонник версии, что все три всадника - св. Георгий. Правда, в человеческой фигуре на крупе коня правого наездника, она видит изображение «архонта Эски-Кермена» [23]. Н.В. Днепровский посчитал возможным выдвинуть следующее предположение: отождествлять четвертую фигуру с персонажем «чуда св. Георгия с отроком» неправильно. Это изображение (взрослого, а не ребенка) является композиционным центром всего храма, позволяя предположить, что это усопший житель Эски-Кермена, именно ради спасения души которого «и был расписан храм». Средний образ - один из двух Федоров (Тирон или Стратилат). Левый однозначно не интерпретируется [8, с. 64].

\section{Церковь «Успения».}

«Успенская церковь - ибо главное изображение на северной стене - Успение. На восточной стене сначала две сиены, разделенные красной с белой полосой горизонтально. Вверху Сретение, внизу неизв[естные] святые в рост (у левого поднята рука, хорошо сохранившаяся, и виден свиток с надписью). Правее в оба яруса фигура святителя в крестчатых ризах с подписью O ПАVAGIO-TABOS APXIЕПI TPI AP / CЕ. Правее его, тоже в рост, фигура мученика. Правее ниши $c<\ldots>$ три головы. Младенец и нимб Богородицы, на южной стене в выбитой нише "Спас". На северной стороне большое углубление для давки винограда, правее по стене маленькое - с канавкой для стока вина.

У деревни Черкес-Кермен. На потолке слева Богоявление с божеством Иордана и рыбами в реке. Спаситель стоит прямо, Иоанн стоит выше, но почти прямо. Рыба одна зеленая, другая - красная. Справа три ангела, слева два ангела.

Правее Рождество Христово.

На алтарной стене, на лобовой стенке слева архангел, справа Богородица ("Благовещение”). В конхе Спас на престоле. Слева остатки Богомате- ри и крылья херувима, справа Предтеча (в рост) наверху плафона.

Под Спасом в конхе композиция: по бокам два святителя, ближе к середине два ангела держащих рипиды (< ..> слева и считаю херувим, другой справа). Bсе совершенно так как в Мангубе (подчеркнуто в подлиннике. - Ю. М., A. E.)» [20, л. 10].

Церковь расположена на юго-восточном краю плато Эски-Кермена. Основным мотивом росписей здесь является изображение сцены Успения Богоматери, отсюда и условное название (рис. 5).

Н.Л. Эрнст датировал церковь XIVXV вв., Н.И. Репников - концом XII - XIII в., О.И. Домбровский - концом XIII - XIV в. (см.: [12, с. 46-48]). Ю.М. Могаричев относил церковь к XIV в. [12, с. 49]. И.Г. Волконская трактует изображение рядом с алтарем как св. Георгия, считая, что «церковь Успения» является храмом Св. Георгия [4, с. 218-223]. Она, как отмечалось, на основании анализа штукатурки посчитала возможным сделать вывод, что данный памятник, как и храм «Трех всадников», были расписаны одной артелью в один сезон. Как мы писали выше, такой подход основан на некорректной выборке образцов для анализа и не может считаться научно обоснованным. Е.Н. Осауленко относит церковь к XIV в., не позднее 1350-1360-х гг. [16, c. 311], и называет ее церковью Св. Георгия и Сергия, имена которых носили погребенные там воины [16, с. 298]. Н.В. Днепровский склоняется к более ранней датировке памятника XII в., считая, что тот являлся церковью Св. Сергия [7, с. 75-85].

В настоящее время роспись сохранилась лишь в алтарной части, где просматриваются фрагменты сюжета Деисус. Выделяются фигуры Спасителя, Богородицы и Иоанна в рост. Ближе к середине - небесные силы, держащие рипиды. Сейчас эти изображения просматриваются небольшими фрагментами. По сторонам от Деисуса, на сводах триумфальной арки Благовещение. Ранее стенопись покрывала практически всю церковь. Северо-восточная стена (слева от алтаря) была разделена на сцены красной полосой с белой каймой: вверху Сретение, внизу - три святых со свитками. Правее, ближе к алтарю, в оба яруса - фигура святителя в ризе с подписью, еще правее фигура мученика. В нише данной стены - изоб- 
ражение младенца и нимб Богородицы. На потолке, слева от алтаря - Богоявление, правее Рождество Христово. Центральный сюжет стенописи Успение Богоматери, практически не просматриваемый ныне, был расположен в северо-западной части храма.

\section{Храм «Донаторов».}

«Ц. Евхаристей. в алтарной конхе видно неясныій Деисус, под ним стенопись Евхаристия налево 3 и направо 3 святителя. Входной справа ОАГ iog NIKA, но левый не святитель, а ангел. И тялнется вниз по нише справа из <..> на северной стене <...> кзападной

ЛАО ЕКОIMN справа от Спасителя по закругленной <..>

Все было расписано следы повсюду, даже на откосах окон

ОА NIКОЛАО

На арке пилястре западной стены черт на своде самого алтаря в плафоне Благовещение. Справа Богородица, слева Гавриил и подпись ГАVРІНЛ.

На своде северного деления <...> ряд фигур из которых ясна голова в нимбе с <..> с подписью О СТРАТІЛАТОС. Левее фрагмент дивный молодой головы (воина), еще левее фрагмент нимба, еще левее в иарской одежде сидящая фигура без нимба (воин).

На плафоне непосредственно после Благовещения к югу Сретение, и к северу Богоявление. У Христа ноги. < .. > Отделены оба сюжета широкой каймой с орнаментом. $<\ldots>$ Благовещение еще на левой части <...> и продолжено на своде.

Ермалай первосвященник 14-й дальше три погрудных медальона

Северная часть выделена арочной стенойнишей. Видимо на середине отделяя как бы северный неф. На арке в начале еще на арочной перегородке от нее такие пророки Св. Евдилий (Ефимий), следующий Вас[илий].

Необычно изыскана вся общая композиция росписей и орнамент (декорат.) убранства. Все это высокое мастерство. Близко к иеркви трех Мучеников» [20, л. 11-12].

Храм «Донаторов» расположен в верховьях балки Черкес-Кермен, к западу от ЭскиКермена. Название происходит от сюжета росписей, изображающих семью донаторов или ктиторов церкви (рис. 6,7$)$.

Первое научное описание памятника выполнил Н.Л. Эрнст [21, с. 32-34]. Исследователь обратил внимание на хорошую сохранность стенописи и на то, что она, в отличие от иных пещерных храмов с фресками, выполнена по более толстому слою штукатурки.

Н.И. Репников датировал церковь сначала второй половиной XIV в. [19, с. 120-122], а затем конкретизировал - 80-егг. XIV в. [18, л. 77].

О.И. Домбровский провел анализ сохранившихся фрагментов росписей и предложил некоторые коррективы в их трактовки $[9$, с. $22-$ 34]. Он полагал, что стенопись была многослойной: первые росписи появились в конце XII начале XIII в. (конха апсиды, фигура всадника), а остальные композиции создавались до конца XIV в., ктитором же выступил местный правитель [9, с. 33-34].

А.Л. Якобсон, согласившись с хронологией Н.И. Репникова, считал, что роспись была создана столичным художником [22, с. 101].

Ю.М. Могаричев, соглашаясь с интерпретацией росписей, предложенной Н.И. Репниковым, полагает, что датировать храм ранее середины XIV в. нет оснований. Он, вслед за А.Л. Якобсоном, пришел к выводу, что церковь являлась частью небольшого монастыря [12, с. 51-53].

По мнению И.Г. Волконской, «предположение О.И. Домбровского о разновременности росписи отдельных частей храма “Донаторов" ни с точки зрения стилистики живописи, ни с точки зрения технологии никак не подтверждается» [4, с. 230]. Она считает, что церковь не может датироваться ранее середины XIV в., а скорее всего, была создана в начале XV века. Данный храм являлся поминальным, в котором «выражена... идея покровительства святых воинов знатной семье» $[4$, с. 231$]$.

Е.Н. Осауленко также датирует памятник второй половиной XIV в. [17, с. 136]. По его мнению, стенопись была выполнена в «неокомниновском» направлении художником - выходцем из Константинополя [17, с. 137].

А.Ю. Виноградов следующим образом прочитал одну из надписей, сохранившихся на фреске (северная стена, восточный аркосолий): «...основан при содействии рабы Христовой Марии. В 6890 (или: 6860) году, в 5-й индикт». Это, по его мнению, позволяет достаточно точно датировать храм 1381-1382 (или 1351-1352) гг. [3].

Таким образом, храм «Донаторов» достаточно обоснованно может датироваться серединой - началом 80-х гг. XIV века. Скорее всего, церковь являлась частью небольшого 


\section{ВИЗАНТИЙСКАЯ ТАВРИКА}

монастыря, ктиторами или донаторами которого была местная знатная семья.

Предположительно, фресками было украшено все внутреннее пространство храма, которое представляло собой сложный живописный ансамбль. На сегодняшний день фрагменты стенописи сохранились в алтаре, на северной и западной стенах, а также на восточной и северной частях свода церкви.

В конхе апсиды выделяется архаичный вариант композиции Деисус (поясной). В апсиде над престолом сохранилось изображение Святителей в рост в крестчатых облачениях. И.Э. Грабарь и О.И. Домбровский считали данное изображение сценой Евхаристии [20, л. 11; 9 , c. 23], Н.И. Репников видел здесь образы Христа-младенца в чаше и пяти святителей по бокам в крестчатых облачениях над алтарем [18, л. 75]. И.Г. Волконская интерпретирует данный фрагмент как композицию Поклонение жертве [4, с. 226]. Е.Н. Осауленко - как Службу святителей и Иисуса-младенца [17, с. 135]. На сводах триумфальной арки алтаря помещена композиция Благовещение: справа - Богородица, слева - архангел Гавриил с соответствующей подписью. Фрагменты этого сюжета хорошо сохранились до сих пор. По этой причине данный сюжет все исследователи трактуют одинаково.

Северная стена и свод северной части потолка имеют наиболее сложную архитектурную организацию. На поверхности стены вырублены две аркосоли, в них изображены фигуры. И.Э. Грабарь ясно рассмотрел Федора Стратилата и несколько фигур в царской одежде без нимбов. Роспись западной стены по своему содержанию и композиционной структуре является продолжением росписи северной стены. Данная часть стенописи сильно повреждена. Это породило большое количество гипотез. Наиболее вероятно, что стенопись данной части храма (северная, западная стены и свод северной части потолка) может содержать изображения св. Федора, Дмитрия Солунского, первоосвященника Ермалая, св. Ефимия, св. Василия, а также фигуры донаторов церкви. В заметках И.Э. Грабаря указано, что на арке пилястры западной стены помешено изображение черта, которое иные исследователи интерпретирует как голову животного, предположительно льва [9, с. $27 ; 17$, с. 135; 4, с. 229]. На плафоне стенопись почти не сохранилась,
И.Э. Грабарь отметил наличие двух композиций непосредственно после Благовещения: к югу - Сретение, к северу - Богоявление.

Результаты. Ранее полностью были опубликованы заметки И.Э. Грабаря только о мангупской церкви. Его размышления о стенописи храмов «Успения» и «Трех всадников» были введены в научный оборот частично, при этом публикаторами были опущены принципиальные моменты, в частности интерпретация изображений святых в «Трех всадниках».

Записки академика о церкви «Донаторов» нами публикуются впервые. Возможно, эта часть заметок не была издана в силу того, что редакторы монографии «О древнерусском искусстве» не смогли идентифицировать памятник. И.Э. Грабарь называл его «церковью Евхаристий», а в историографии он известен как храм «Донаторов».

Игорь Эмануилович отмечал, что наиболее значимая живопись представлена в храмах «Трех всадников» и «Донаторов». Вероятно, такому выводу способствовала и лучшая сохранность этих росписей по сравнению с иными памятниками.

Гипотеза о датировке начального этапа живописи мангупской церкви XIV в. (равно как и ее сходство с росписями храма «Успения») ныне не находит подтверждения. Однако Игорь Эмануилович - первый, кто подметил: стенопись там была созданы в несколько этапов (три, по нашему мнению).

Заключение И.Э. Грабаря позволяет обоснованно отбросить версии о «трех Георгиях» и «портретах реальных местных деятелей» в живописи храма «Трех всадников». Перед нами изображение трех святых воинов: Дмитрия, Феодора (Стратилата или Тирона) и Георгия. Собственно, об этом говорит и надпись под фреской, что позволяет исключить версию об одном св. Георгии.

\section{ПРИМЕЧАНИЯ}

${ }^{1}$ В настоящей работе мы издаем только два ранее не опубликованных рисунка И.Э. Грабаря (остальные см.: [6, с. 259]).

${ }^{2}$ Курсивом указан ранее не публиковавшийся текст.

${ }^{3}$ Мы даем ссылки только на работы, не вошедшие в историографический обзор [15, с. 274-278]. 


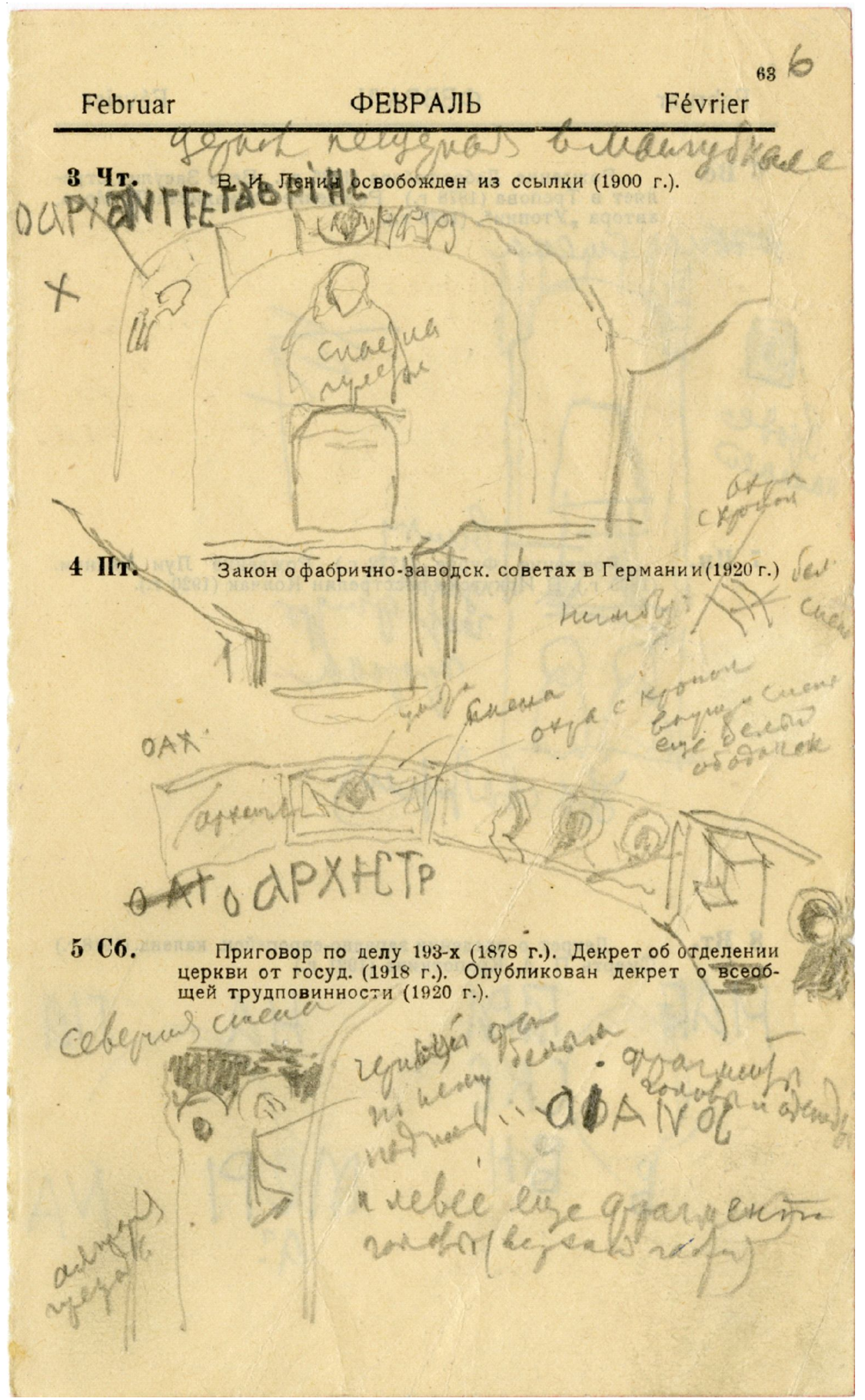

Рис. 1. Пещерная церковь Южного монастыря (Мангуп) по И.Э. Грабарю. Алтарь [20, л. 6]

Fig. 1. Mangup. Temple of the South Monastery. Altar. The scheme by I.E. Grabar [20, 1. 6] 


\section{ВИЗАНТИЙСКАЯ ТАВРИКА}

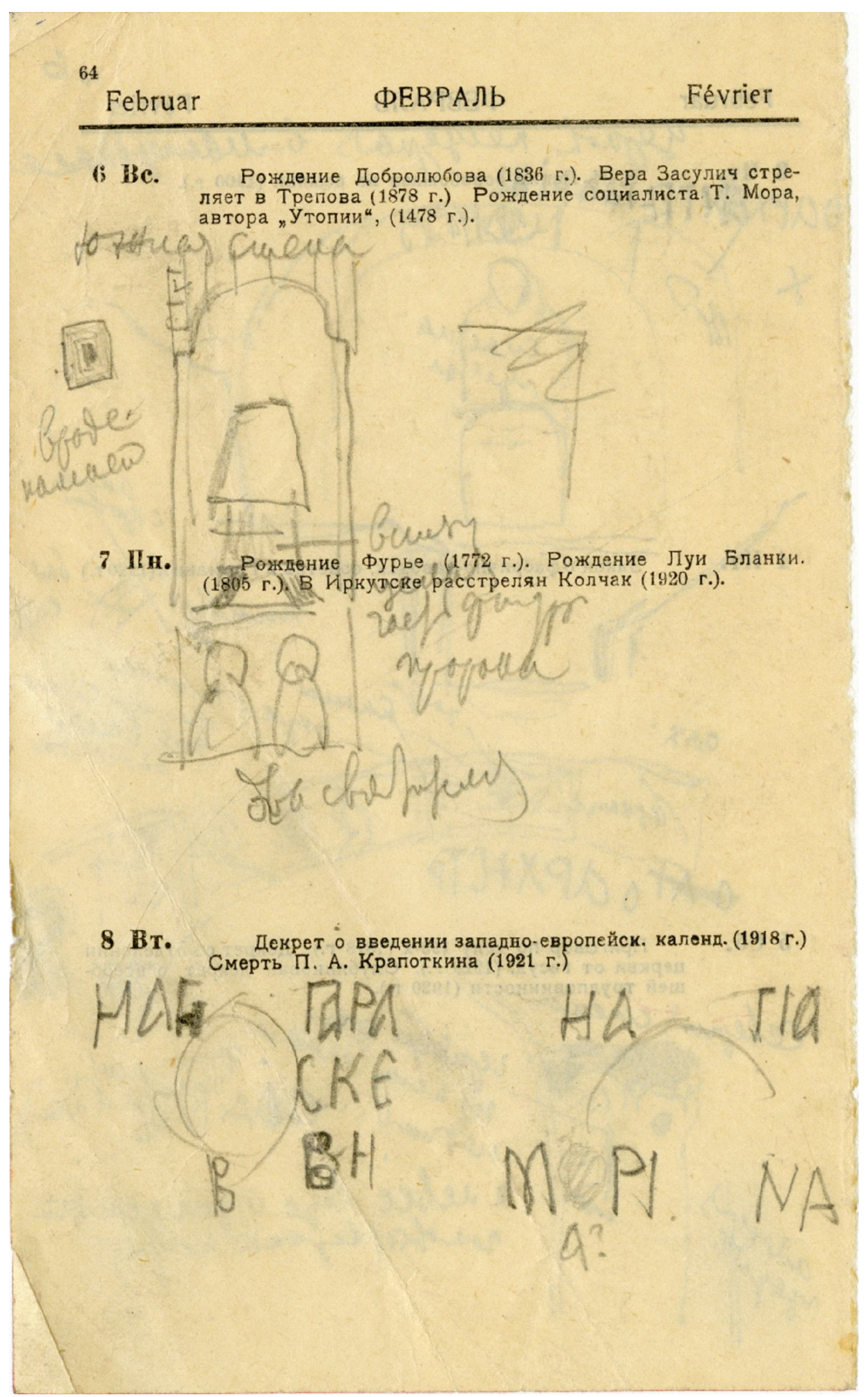

Рис. 2. Пещерная церковь Южного монастыря (Мангуп) по И.Э. Грабарю. Южная стена [20, л. 6 об.]

Fig. 2. Mangup. Temple of the South Monastery. The south wall. The scheme by I.E. Grabar [20,1. 6 ob.] 


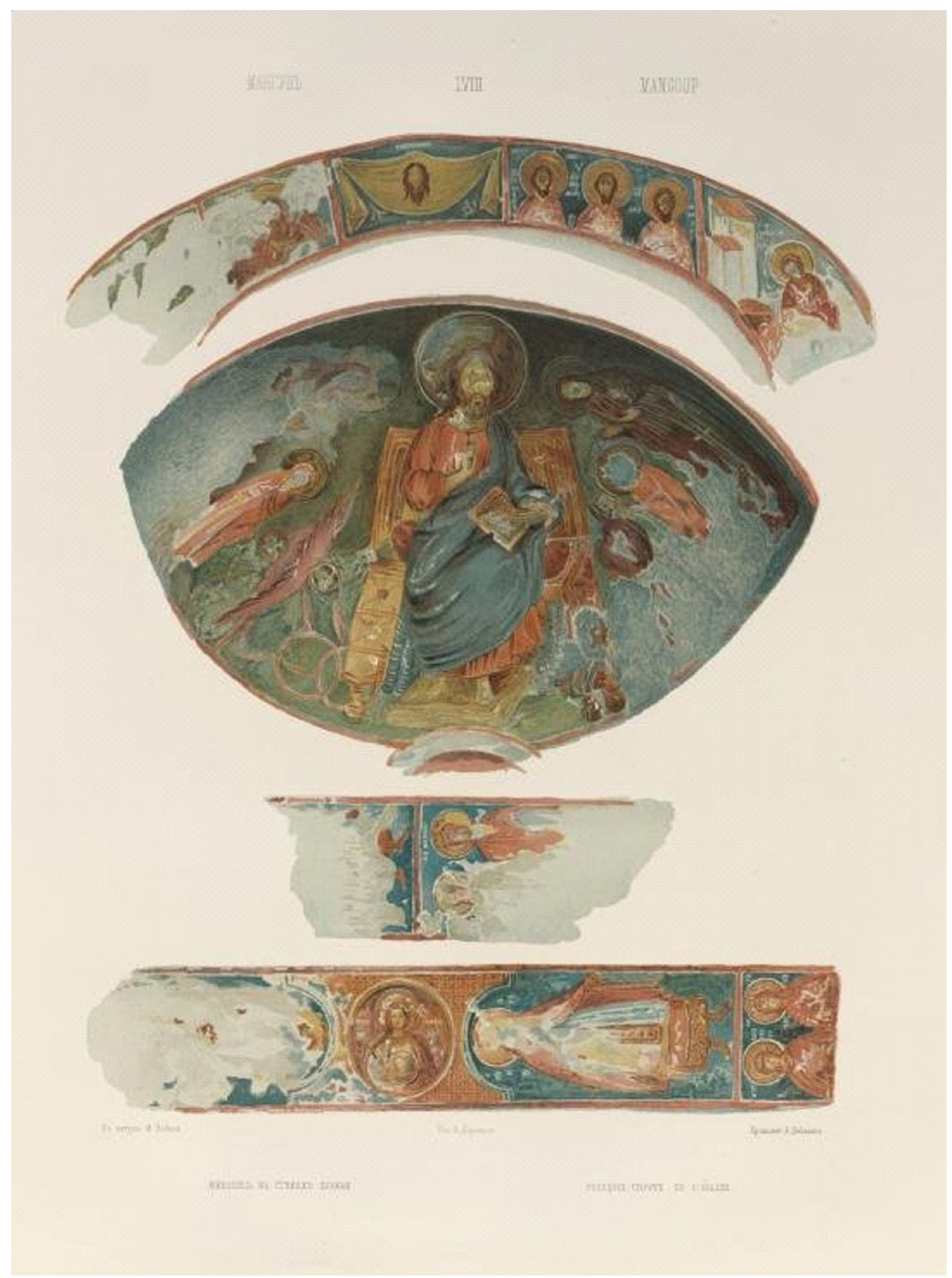

Рис. 3. Пещерная церковь Южного монастыря (Мангуп). Фресковые росписи.

Из неизданного альбома А.С. Уварова (середина ХІХ в.)

Fig. 3. Mangup. Temple of the South Monastery. Fresco paintings.

From unedited album of A.S. Uvarov (mid-19 $9^{\text {th }}$ century) 


\section{ВИЗАНТИЙСКАЯ ТАВРИКА}

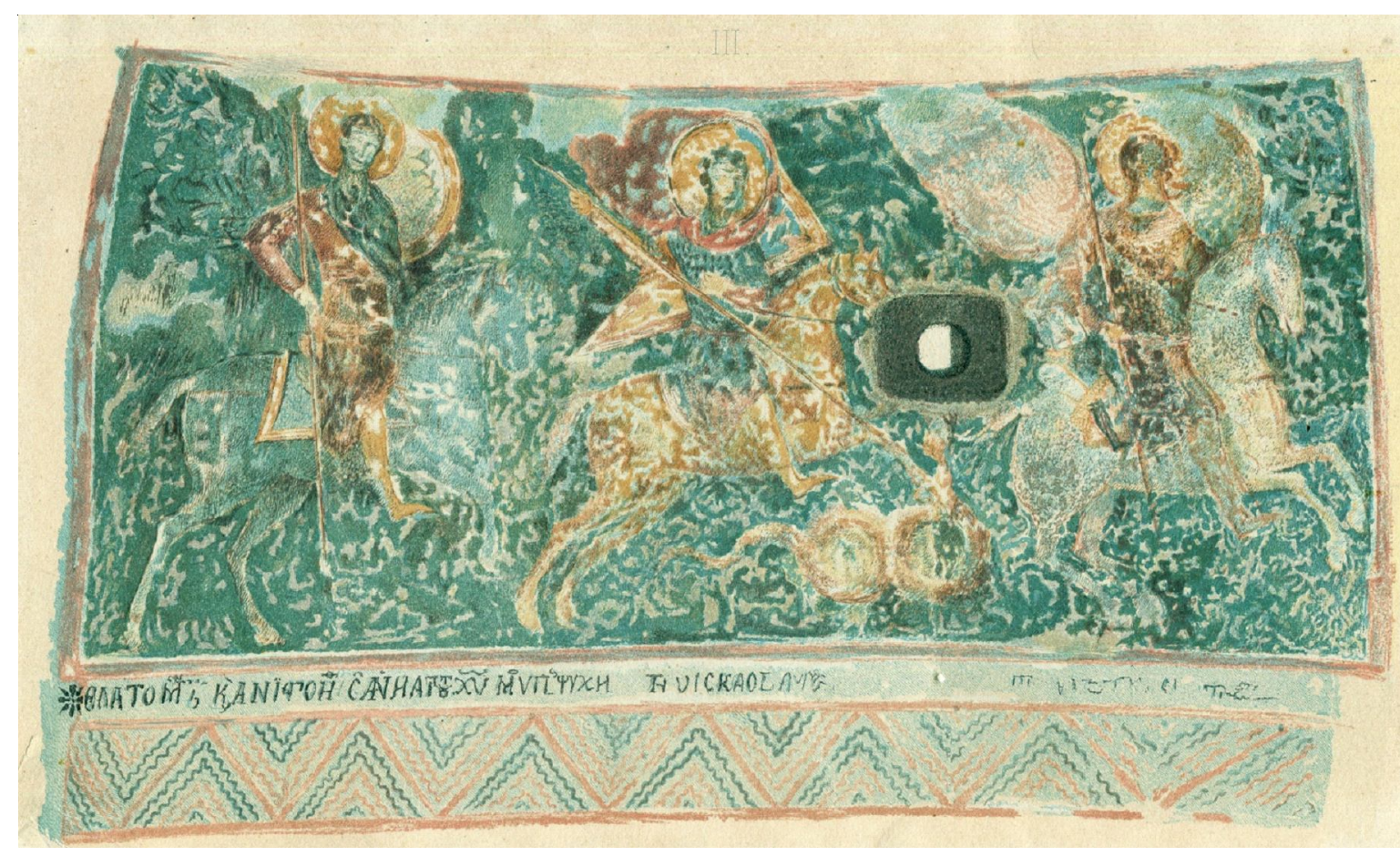

Рис. 4. Церковь «Трех всадников» (Эски-Кермен). Фресковые росписи. Из неизданного альбома А.С. Уварова (середина XIX в.)

Fig. 4. Fig. 4. Eski Kermen. Temple of Three riders. Fresco paintings. From unpublished album of A.S. Uvarov (mid-19 $9^{\text {th }}$ century)

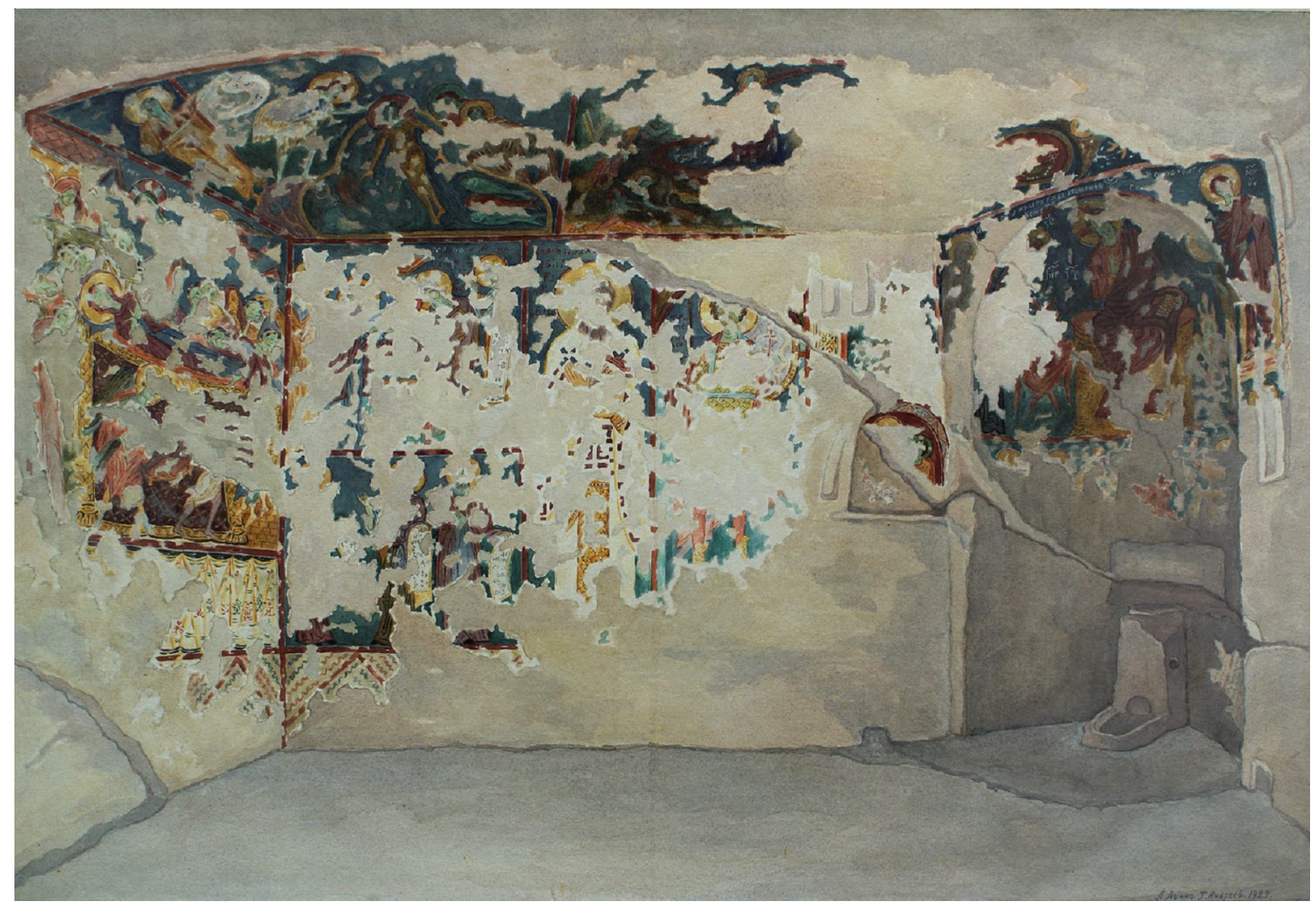

Рис. 5. Церковь «Успения» (Эски-Кермен). Фресковые росписи. С рис. Л. Линно и Г. Андреева. 1928 г.

Fig. 5. Eski Kermen. Temple of Assumption. Fresco paintings. Drawings by L. Lynno and G. Andreev. 1928 


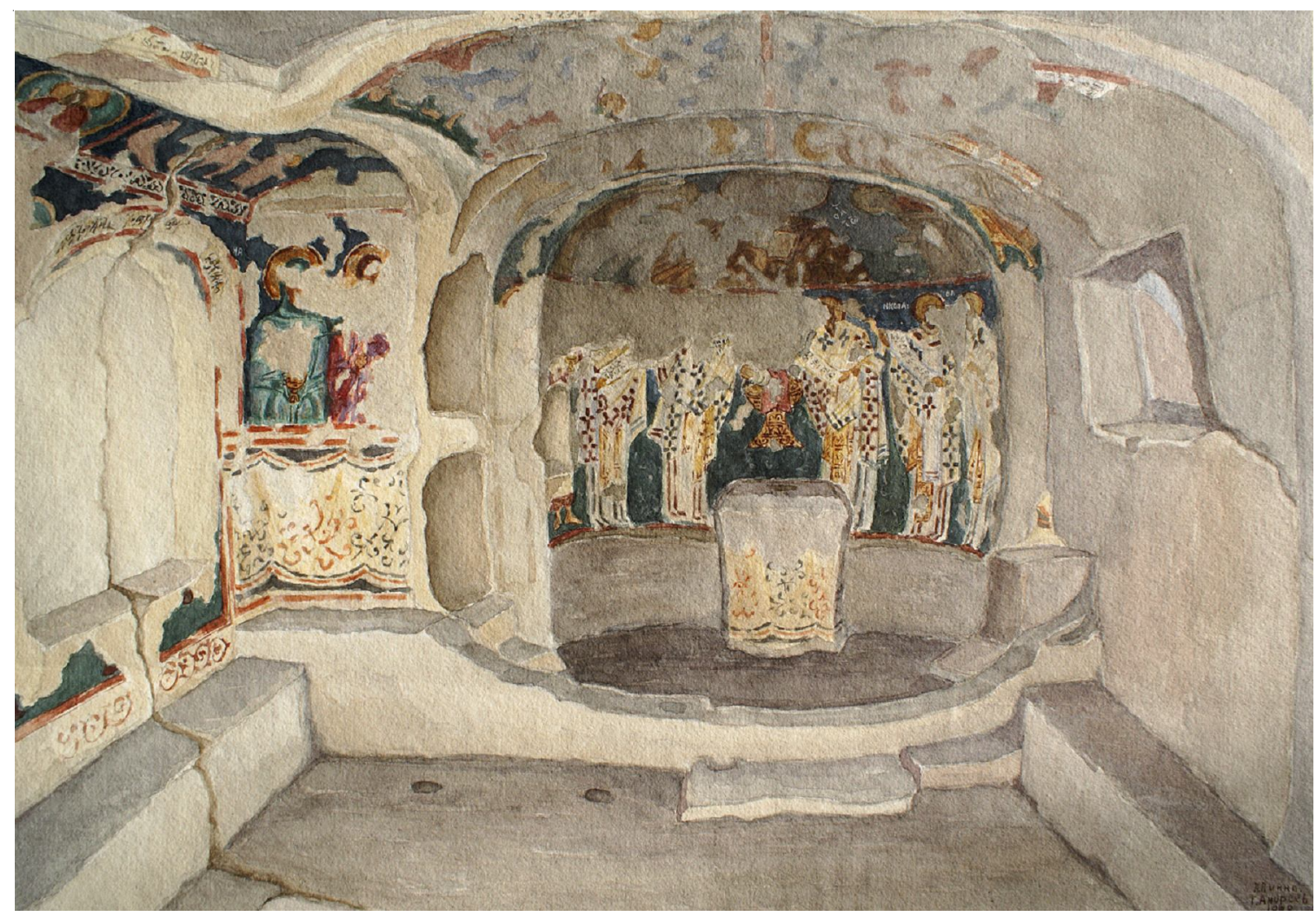

Рис. 6. Храм «Донаторов» (округа Эски-Кермена). Алтарная часть. Фресковые росписи. С рис. Л. Линно и Г. Андреева. 1928 г.

Fig. 6. Eski Kermen. Temple of Donators. Altar. Fresco paintings. Drawings by L. Lynno and G. Andreev. 1928

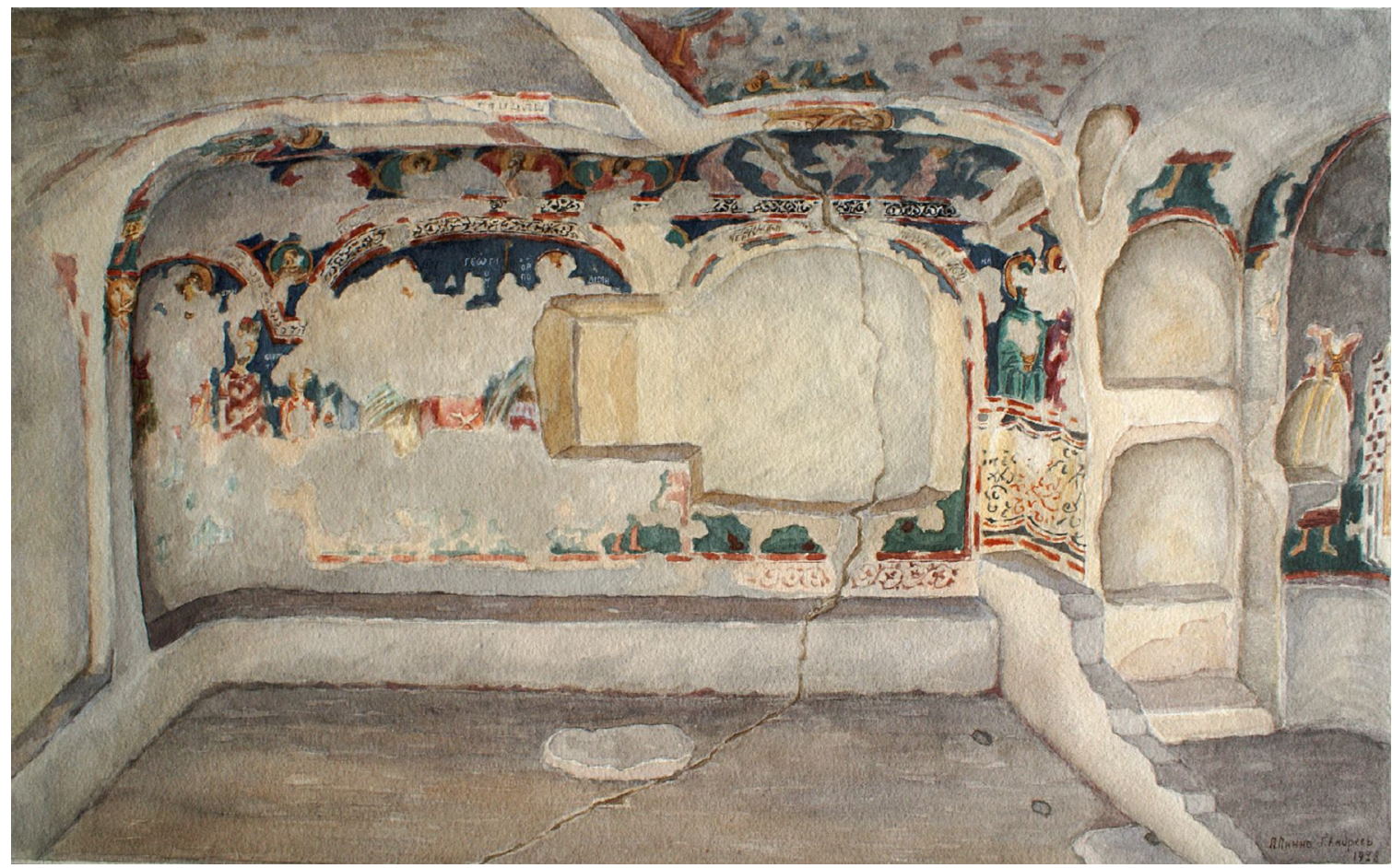

Рис. 7. Храм «Донаторов» (округа Эски-Кермена). Северная стена. Фресковые росписи. С рис. Л. Линно и Г. Андреева. 1928 г.

Fig. 7. Eski Kermen. Temple of Donators. North wall. Fresco paintings. Drawings by L. Lynno and G. Andreev. 1928 


\section{СПИСОК ЛИТЕРАТУРЫ}

1. Атанасов, Г. Свети Георги Победоносец. Култ и образ в православния изток през средновиковието / Г. Атанасов. - София : Зограф, 2001. $364 \mathrm{c}$.

2. Бобровский, Т. А. Пещерная церковь с фресками византийской эпохи в Юго-Западном Крыму/ Т. А. Бобровский, Е. Е. Чуева // Материалы Международной церковно-исторической конференции «Духовное наследие Крыма» памяти преподобного Иоанна, Епископа Готфского. - Симферополь : Изд-во Симфероп. и Крым. епархии, 2006. C. 181-223.

3. Виноградов, А. Ю. Черкес-Кермен. Строительная надпись Марии, 1351-1352 или 1381-1382 гг. / А. Ю. Виноградов // Византийские надписи. Древние надписи Северного Причерноморья (IOSPE).Электрон. текстовые дан. - Режим доступа: https:// iospe.kcl.ac.uk/5.209-ru.html (дата обращения: 06.04.2020). - Загл. с экрана.

4. Волконская, И. Г. Эски-Керменские фрески. Новые исследования / И. Г. Волконская // Церковные древности. - Симферополь : Универсум, 2005. - C. 217-239.

5. Гайдуков, Н. Е. Литургические датировки некоторых пещерных храмов Таврики / Н. Е. Гайдуков // О древностях Южного берега Крыма и гор Таврических. - Киев : Стилос, 2004. - С. 167-174.

6. Грабарь, И. Э. О древнерусском искусстве. Исследование, реставрация и охрана памятников / И. Э. Грабарь. - М. : Наука, 1966. - 386 с.

7. Днепровский, Н. В. К вопросу о валидности некоторых критериев датировки фресковой росписи эски-керменского храма «Успения» / Н. В. Днепровский // Бахчисарай: археология, история, этнография. - Бахчисарай ; Белгород : Константа, 2018. C. $70-87$.

8. Днепровский, Н. В. Некоторые проблемы исследования фрески Эски-Керменского храма «Трех всадников» / Н. В. Днепровский // Бахчисарай: археология, история, этнография. - Бахчисарай ; Белгород : Константа, 2018. - С. 55-69.

9. Домбровский, О. И. Фрески средневекового Крыма / О. И. Домбровский. - Киев : Изд-во АН УССР, 1966. - 110 c.

10. Ергина, А. С. К истории изучения стенописи пещерных городов Крыма в 1920-1930-е гг. / А. С. Ергина // Вестник Санкт-Петербургского государственного университета технологии и дизайна. Серия 2, Искусствоведение. Филологические науки. - 2019. - № 4-С. 29-33.

11. Латышев, В. В. Заметки к христианским надписям из Крыма / В. В. Латышев // Записки Одесского общества истории и древностей. - 1897. T. XX. - C. 149-162.
12. Могаричев, Ю. М. Пещерные церкви Таврики / Ю. М. Могаричев. - Симферополь : Таврия, 1997. $-384 \mathrm{c}$.

13. Могаричев, Ю. М. К вопросу о периодизации фресковых росписей пещерной церкви Южного монастыря Мангупа / Ю. М. Могаричев, А. С. Ергина // Вестник Волгоградского государственного университета. Серия 4, История. Регионоведение. Международные отношения. - 2019. - Т. 24, № 6. - С. 47-63. DOI: https://doi.org/10.15688/jvolsu4.2019.6.4.

14. Могаричев, Ю. М. Пещерная церковь на поляне Кильсе-Тубю (округа Мангупа, Крым) / Ю. М. Могаричев, А. С. Ергина // Проблемы истории, филологии, культуры. - 2019. - № 3. C. 166-186. - DOI: https://doi.org/10.18503/19920431-2019-3-65-166-186.

15. Могаричев, Ю. М. «Пещерные города» Горной Юго-Западной Таврики в описании А.С. Уварова / Ю. М. Могаричев. - Симферополь : Бизнес-Информ, 2019. - 344 с.

16. Осауленко, Є. М. Відображення візантійської аскетичної естетики в мистецтві Кримської Готії початку XV століття на прикладі розписів печерної церкви «Південного монастиря» на Мангупі / С. М. Осауленко // Лаврський альманах. Київ. -2007. - Вип. 17. C. 292-311.

17. Осауленко, Є. М. Збираючи мозаїку знов : Середньовічні фрески Кримської Готії / С. М. Осауленко // Collegium. - 2008. - № 24. - C. 127-146.

18. Репников, Н. И. Материалы к археологической карте Юго-Западного нагорья Крыма / Н. И. Репников // Архив Института истории материальной культуры РАН. - Ф. 10. - Д. 10. - 387 л.

19. Репников, Н. И. Эски-Кермен в свете археологических разведок 1928-29 гг. / Н. И. Репников // Известия Государственной академии истории материальной культуры. Готский сборник. 1932. - Т. 12, вып. 1-8. - С. 107-152.

20. Черновые заметки И.Э. Грабаря о поездке в Крым и о древнерусском искусстве [1929] // Рукописный отдел Государственной Третьяковской галереи. - Ф. 106. - Оп. 4. - Ед. хр. 590а. - 24 л.

21. Эрнст, Н. Л. Эски-Кермен и пещерные города Крыма / Н. Л. Эрнст // Известия Таврического общества истории, археологии и этнографии. 1929. - Т. 3 (60). - С. 15-43.

22. Якобсон, А. Л. Средневековый Крым / А. Л. Якобсон. - М. ; Л. : Наука, 1964. - 232 с.

23. Plontke-Luning, A. Ein Jerrn vom Eski-Kermen? Uberlegungen zum Dreireiter-Bild in der Felskapelle am sudwesthang des Eski-Kermen / A. Plontke-Luning // Die Höhensiedlungen im Bergland der Krim. Umwelt, Kulturaustausch und Transformation am Nordrand des Byzantinischen Reiches / hrsg. von S. Albrecht, F. Daim, M. Herdick. - Mainz : Verl. des Römisch-Germanischen Zentralmuseums, 2013. -S. 251-269. 


\section{REFERENCES}

1. Atanasov G. Sveti Georgi Pobedonosets. Kult i obraz v pravoslavniya iztok prez srednovikovieto [St. George the Victorious. Orthodoxy in the Origins of the Middle Ages]. Sofiya, Zograf Publ., 2001. 364 p.

2. Bobrovskiy T.A., Chueva E.E. Peshchernaya tserkov s freskami vizantiyskoy epokhi v YugoZapadnom Krymu [Cave church with frescoes of the Byzantine era in the South-Western Crimea] Materialy Mezhdunarodnoy tserkovno-istoricheskoy konferentsii «Dukhovnoe nasledie Kryma» pamyati prepodobnogo Ioanna, Episkopa Gotfskogo [Materials of the International Church-Historical Conference "Spiritual Heritage of Crimea" in memory of St. John, Bishop of Gotfsky]. Simferopol, Izd-vo Simferopolskiy i Krymskoy eparkhii Publ., 2006, pp. 181-223.

3. Vinogradov A.Yu. Cherkes-Kermen. Stroitelnaia nadpis Marii, 1351-1352 ili 1381-1382 gg. [Circassian-Kermen. Construction inscription of Mary, 1351-1352 or 1381-1382] // Vizantiyskie nadpisi. Drevnie nadpisi Severnogo Prichernomorya (IOSPE). URL: http://iospe.kcl.ac.uk/5.152-ru.html (accessed 6 April 2020).

4. Volkonskaya I.G. Eski-Kermenskie freski. Novye issledovaniya [The Frescoes of Eski-Kermen. The new studies]. Tserkovnye drevnost $i$ [The church antiquities]. Simferopol, Universum Publ., 2005, pp. 217-239.

5. Gaydukov N.E. Liturgicheskie datirovki nekotorykh peshchernykh khramov Tavriki [The liturgical dating of certain cave churches]. O drevnostyakh Yuzhnogo berega Kryma $i$ gor Tavricheskikh [On antiquities of the Southern Coast ofCrimea and Taurical Mountains]. Kiev, Stilos Publ., 2004, pp. 167-174.

6. Grabar I.E. O drevnerusskom iskusstve. Issledovanie, restavratsiya i okhrana pamyatnikov [About Old Russian Art. Study, Restoration and Protection of Monuments]. Moscow, Nauka Publ., 1966. $386 \mathrm{p}$.

7. Dneprovskiy N.V. K voprosu o validnosti nekotorykh kriteriev datirovki freskovoy rospisi eskikermenskogo khrama «Uspeniya» [To the question of the validity of some criteria for dating fresco paintings of the Eski-Kermen church of the Assumption]. Bakhchisarai: arkheologiya, istoriya, etnografiya [Bakhchisaray: archaeology, history, ethnography]. Bakhchisarai; Belgorod, Konstanta Publ., 2018, pp. 70-87.

8. Dneprovskii N.V. Nekotorye problemy issledovaniya freski Eski-Kermenskogo khrama «Trekh vsadnikov» [Some problems of the study of the frescoes of the Eski-Kermen temple "Three Horsemen"]. Bakhchisaray: arkheologiya, istoriya, etnografiya [Bakhchisaray: archaeology, history, ethnography]. Bakhchisaray; Belgorod, Konstanta Publ., 2018, pp. 55-69.

9. Dombrovskiy O.I. Freski srednevekovogo Kryma [The Frescoes of Medieval Crimea]. Kiev, Izd-vo AN USSR Publ., 1966. 110 p.

10. Ergina A. S. K istorii izucheniya stenopisi peshchernykh gorodov Kryma v 1920-1930-e gg. [On the history of studying the mural paintings of cave cities of Crimea in the 1920-1930s.]. Vestnik SanktPeterburgskogo gosudarstvennogo universiteta tekhnologii i dizaina. Seriya 2: Iskusstvovedenie. Filologicheskie nauki [Vestnik of St. Petersburg State University of Technology and Design. Series 2. Art criticism. Philological sciences]. 2019, no. 4, pp. 29-33.

11. Latyshev V.V. Zametki k khristianskim nadpisyam iz Kryma [Notes to Christian inscriptions from Crimea] Zapiski Odesskogo obshchestva istorii $i$ drevnostey [Notes of the Odessa Society of History and Antiquities], 1897, vol. XX, pp. 149-162.

12. Mogarichev Yu.M. Peshchernye tserkvi Tavriki [The Cave Churches of Taurica]. Simferopol, Tavriya Publ., 1997. 384 p.

13. Mogarichev Yu.M. "Peshchernye goroda" Gornoy Yugo-Zapadnoy Tavriki v opisanii A.S. Uvarova ["Cave cities" of the Mountain SouthWestern Taurica in the description of A.S. Uvarova]. Simferopol, Biznes-Inform Publ., 2019. 344 p.

14. Mogarichev Yu.M., Ergina A.S. Reassessing the Periodization of Mural Paintings in the Cave Church of the Southern Mangup Monastery. Vestnik Volgogradskogo gosudarstvennogo universiteta. Seriya 4. Istoriya. Regionovedenie. Mezhdunarodnye otnosheniya [Science Journal of Volgograd State University. History. Area Studies. International Relations], 2019, vol. 24, no. 6, pp. 47-63. DOI: https:// doi.org/10.15688/jvolsu4.2019.6.4.

15. Mogarichev Yu. M., Ergina A. S. Peshchernaya tserkov na polyane Kilse-Tubyu (okruga Mangupa, Krym) [Cave church on the clearing Kilsa-Tubu (Mangupa district, Crimea)] Problemy istorii, filologii, kultury [Problems of history, philology, culture], 2019, no. 3, pp. 166-186. DOI: https://doi.org/10.18503/19920431-2019-3-65-166-186.

16. Osaulenko Ie.M. Vidobrazhennia vizantiiskoi asketychnoi estetyky v mystetstvi Krymskoi Gotii pochatku XV stolittia na prykladi rozpysiv pechernoi tserkvy "Pivdennogo monastyria" na Mangupi [The Reflection of the Byzantine Ascetic Aesthetics in the Art of the Crimean Gothic Beginning of the Fifteenth Century on the Example of the Paintings of the Cave Church "Southern Monastery" in Mangup]. Lavrskyi almanakh [Lavra Almanac]. 2007, vol. 17, pp. 292-311.

17. Osaulenko Ie.M. Zbirayuchi mozaiku znov: serednovichni freski Krymskoi Gotii [Assembling the mosaic again: the medieval frescoes of Crimean Gothic] Collegium, 2008, no. 24, pp. 127-146. 


\section{ВИЗАНТИЙСКАЯ ТАВРИКА}

18. Repnikov N.I. Materialy k arkheologicheskoy karte Yugo-Zapadnogo nagorya Kryma [The matters on archeological map of Southwest Plateau of Crimea]. Arkhiv Instituta istorii materialnoy kultury $R A N$ [Archive of the Institute of History of Material Culture of the Russian Academy of Science], f. 10, d. 10.3871 .

19. Repnikov N.I. Eski-Kermen v svete arkheologicheskikh razvedok 1928-29 gg. [EskiKermen in the light of archaeological exploration at 1928-1929]. Izvestiya gosudarstvennoy akademii istorii materialnoy kultury. [Bulletin of the State Academy for History of Material Culture], 1932, vol. 12, iss. $1-8$, pp. $107-152$.

20. Chernovye zametki I.E. Grabarya o poezdke v Krym i o drevnerusskom iskusstve (1929) [Draft notes by I.E. Grabar about a trip to the Crimea and about ancient Russian art (1929)]. Rukopisnyy otdel Gosudarstvennoy Tretyakovskoy galerei
[Manuscripts Department of the State Tretyakov Gallery], f. 106, op. 4, ed. khr. 590a. 241.

21. Ernst N.L. Eski-Kermen i peshchernye goroda Kryma [Eski-Kermen and Crimean Cave Towns]. Izvestiya Tavricheskogo obshchestva istorii, arkheologii i etnografii [News of the Tauride Society of history, archaeology and ethnography], 1929, vol. 3 (60), pp. 15-43.

22. Yakobson A.L. Srednevekovyy Krym [The Medieval Crimea]. Moscow; Leningrad, Nauka Publ., 1964.232 p.

23. Plontke-Luning, A. Ein Jerrn vom Eski-Kermen? Uberlegungen zum Dreireiter-Bild in der Felskapelle am sudwesthang des Eski-Kermen / A. Plontke-Luning // Albrecht S., Daim F., Herdick M., eds. Die Höhensiedlungen im Bergland der Krim. Umwelt, Kulturaustausch und Transformation am Nordrand des Byzantinischen Reiches. Mainz, Verl. des RömischGermanischen Zentralmuseums, 2013, pp. 251-269.

\section{Information About the Authors}

Yuriy M. Mogarichev, Doctor of Sciences (History), Professor, Leading Researcher, Institute of Archaeology of Crimea of the Russian Academy of Sciences, Prosp. Akademika Vernadskogo, 2, 295007 Simferopol, Russian Federation; Head of the Humanity and Social Science Department, Crimean Republican Institute of Postgraduate Pedagogical Education, Lenina St, 15, 295051 Simferopol, Russian Federation, mogara@rambler.ru, https://orcid.org/0000-0001-6057-2316

Alena S. Ergina, Postgraduate Student, Department of Art History, Saint Petersburg State Academy of Arts and Design named after A.L. Stieglitz, Solyanoy Lane, 13, 191028 Saint Petersburg, Russian Federation, yergina.alyona@gmail.com, https://orcid.org/0000-0001-7988-0415

\section{Информация об авторах}

Юрий Миронович Могаричев, доктор исторических наук, профессор, ведущий научный сотрудник, Институт археологии Крыма РАН, просп. Академика Вернадского, 2, 295007 г. Симферополь, Российская Федерация; заведующий кафедрой социального и гуманитарного образования, Крымский республиканский институт постдипломного педагогического образования, ул. Ленина, 15, 295051 г. Симферополь, Российская Федерация, mogara@rambler.ru, https://orcid.org/ 0000-0001-6057-2316

Алена Сергеевна Ергина, аспирант кафедры искусствоведения, Санкт-Петербургская государственная художественно-промышленная академия им. А.Л. Штиглица, пер. Соляной, 13, 191028 г. Санкт-Петербург, Российская Федерация, yergina.alyona@gmail.com, https://orcid.org/0000-0001-7988-0415 